\title{
Pharmacological study of anti-allergic activity of Syzygium cumini (L.) Skeels
}

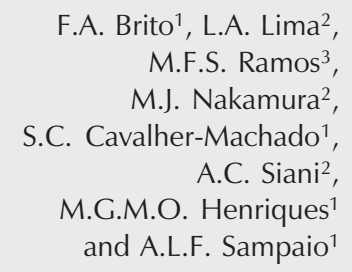

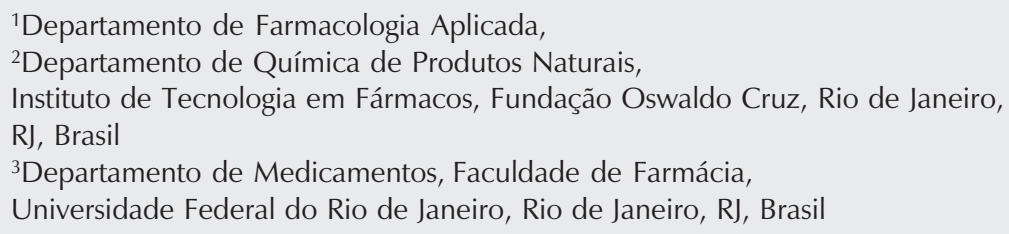

\section{Correspondence}

M.G.M.O. Henriques

Departamento de Farmacologia

Aplicada

FarManguinhos, FIOCRUZ

R. Sizenando Nabuco, 100

21041-250 Rio de Janeiro, RJ

Brasil

Fax: +55-21-2564-2559

E-mail: gracahenriques@fiocruz.br

Research supported by CNPq.

F.A. Brito is the recipient of a

post-graduated fellowship from CAPES.

Received June 15, 2005 Accepted October 6, 2006 $\ldots \ldots \ldots \ldots \ldots \ldots$

\section{Abstract}

Myrtaceae is a plant family widely used in folk medicine and Syzygium and Eugenia are among the most important genera. We investigated the anti-allergic properties of an aqueous leaf extract of Syzygium cumini (L.) Skeels (SC). HPLC analysis revealed that hydrolyzable tannins and flavonoids are the major components of the extract. Oral administration of SC (25-100 mg/kg) in Swiss mice (20-25 g; $\mathrm{N}=7$ /group) inhibited paw edema induced by compound $48 / 80(50 \%$ inhibition, $100 \mathrm{mg} / \mathrm{kg} ; \mathrm{P} \leq 0.05)$ and, to a lesser extent, the allergic paw edema (23\% inhibition, $100 \mathrm{mg} / \mathrm{kg}$; $\mathrm{P} \leq 0.05$ ). SC treatment also inhibited the edema induced by histamine ( $58 \%$ inhibition; $\mathrm{P} \leq 0.05$ ) and 5-HT (52\% inhibition; $\mathrm{P} \leq 0.05)$ but had no effect on plateletaggregating factor-induced paw edema. SC prevented mast cell degranulation and the consequent histamine release in Wistar rat (180$200 \mathrm{~g} ; \mathrm{N}=7 /$ group) peritoneal mast cells (50\% inhibition, $1 \mu \mathrm{g} / \mathrm{mL}$; $\mathrm{P} \leq 0.05$ ) induced by compound $48 / 80$. Pre-treatment of BALB/c mice (18-20 g; $\mathrm{N}=7 /$ group) with $100 \mathrm{mg} / \mathrm{kg}$ of the extract significantly inhibited eosinophil accumulation in allergic pleurisy (from $7.662 \pm$ 1.524 to $1.89 \pm 0.336 \times 10^{6}$ cavity; $\left.\mathrm{P} \leq 0.001\right)$. This effect was related to the inhibition of IL-5 (from $70.9 \pm 25.2$ to $12.05 \pm 7.165 \mathrm{pg} / \mathrm{mL}$ ) and CCL11/eotaxin levels (from $60.4 \pm 8.54$ to $32.8 \pm 8.4 \mathrm{ng} / \mathrm{mL}$ ) in pleural lavage fluid, using ELISA. These findings demonstrate an anti-allergic effect of SC, and indicate that its anti-edematogenic effect is due to the inhibition of mast cell degranulation and of histamine and serotonin effects, whereas the inhibition of eosinophil accumulation in the allergic pleurisy model is probably due to an impairment of CCL11/eotaxin and IL-5 production.
Key words

- Myrtaceae

- Syzygium cumini

- Allergy

- Paw edema

- Pleurisy

- Cytokine

\section{Introduction}

Myrtaceae is a plant family widely used in folk medicine in different countries and Eugenia and Syzygium are among its most important genera. Species of this family are often used for several medicinal purposes, including the treatment of diarrhea (1) and pain. Experimental data also suggest the action of these species on inflammatory pro- 
cesses, respiratory diseases (2), and allergic disorders (3). The seeds of Syzygium cumini (L.) Skeels (SC; Myrtacea, syn., Eugenia jambolana Lamk) have been reported to be useful as astringents in diarrhea as well as dysentery (4). Other parts of the plant have been reported to possess anti-diabetic (5), bactericidal (6) and anti-mutagenic (7) properties. The ethanolic bark extract has been reported to have anti-inflammatory activity in carrageenan and formaldehyde paw edema (2). The same extract was also shown to inhibit histamine-, serotonin (5-HT)- and prostaglandin 2-induced paw edema (8).

The allergic process has an important inflammatory component in which mast cell activation and degranulation are the first phenomena observed. During this process, mast cells release several inflammatory mediators including histamine, 5-HT, plateletaggregating factor (PAF), leukotrienes, and a variety of cytokines which can elicit many events associated with allergic inflammation, such as edema formation and cellular infiltration (9). Eosinophil accumulation is the main feature of allergic inflammation, these being some of the most abundant leukocytes present at the site. The triggering and regulation of eosinophil accumulation in allergic inflammation depend on the release of cytokines and chemokines such as interleukin-4 (IL-4), IL-5 and CCL11/eotaxin in response to an antigen challenge $(10,11)$. Once they reach the allergic site, eosinophils degranulate and release several mediators, including leukotrienes, major basic protein, PAF, cationic protein, and eosinophil-derived neurotoxin that contribute to extensive tissue damage (12). The modulation of eosinophil accumulation is one of the main targets for the discovery of anti-allergic compounds because of its potential tissue damaging effects.

In the present study, we investigated the ability of an aqueous leaf extract of SC to inhibit mouse allergic edema formation and eosinophil accumulation in mouse allergic pleurisy and the mechanisms involved in such phenomena

\section{Material and Methods}

\section{Material}

Compound 48/80 (C48/80), ovalbumin (OVA, grade V), histamine, PAF, 5-HT, dexamethasone, disodium cromoglycate, $3 \%$ PBS/milk, PBS, o-phtaldialdehyde, HBSS, complete Freund's adjuvant, and all other highest grade reagents were purchased from Sigma (St. Louis, MO, USA). WEB2170 was obtained from Boehringer-Ingelheim (Ingelheim, Germany), Percoll was from Amersham Pharmacia Biotech AB (Uppsala, Sweden); May-Gruenwald-Giemsa, Toluidine blue and Trypan blue were purchased from Merck (Rio de Janeiro, RJ, Brazil).

\section{Animals}

Male Swiss Webster (20-25 g) and BALB/ c mice (18-20 g) and Wistar rats (180-200 g) from our own colony (CECAL-FIOCRUZ) were housed in a room with controlled temperature and lighting, with free access to lab chow and tap water. All experiments were conducted in accordance with the ethical guidelines of the International Association for the Study of Pain (13) and the institutional guidelines for animal use (CEUA 00050/00).

\section{Plant material and extract preparation}

Entire branches of SC were collected in Rio de Janeiro in January 1999. The plant material was identified by Dr. Graziela M. Barrozo (in memoriam), Botanic Garden of Rio de Janeiro, and a voucher was deposited in the Herbarium of the Botanic Garden of Rio de Janeiro under number HB-83016. The aqueous extract of fresh leaves of SC was obtained by decoction of leaves in distilled water $(100 \mathrm{~g} / \mathrm{L})$ for 3 to $5 \mathrm{~min}$. The 
extract was filtered, lyophilized, stored at room temperature, and dissolved in distilled water immediately before use.

\section{HPLC characterization of the extract}

The separation of the components of the mixture was dependent on the $\mathrm{pH}$ of the mobile phase, with $\mathrm{pH}$ near 4 being satisfactory. Thus, $0.1 \%$ phosphoric acid was added to the mobile phase to adjust its $\mathrm{pH}$ to 4.1 . The mobile phase eluted all the phenolic compounds within $30 \mathrm{~min}$ at $0.75 \mathrm{~mL} / \mathrm{min}$. Analysis was performed on a Supelcosil LC $18(250 \mathrm{~mm} \times 4.6 \mathrm{~mm}$, I.D., $5 \mu \mathrm{m}$ particle size) column.

A 40.0-mg sample of the extract was accurately weighed and transferred to a 3.00$\mathrm{mL}$ microcentrifuge tube, suspended in 2.00 $\mathrm{mL}$ methanol and cooled in an ice bath. The suspension was sonicated (Odontrobrás, Ribeirão Preto, SP, Brazil) for 20 min and then centrifuged for $10 \mathrm{~min}$ at $3000 \mathrm{rpm}$, at $4^{\circ} \mathrm{C}$ (Beckman Coulter, Fullerton, CA, USA). The supernatant was decanted and stored at $-20^{\circ} \mathrm{C}$. Before injection into the column, the samples were filtered in an UltraFree-MC 0.22- $\mu \mathrm{m}$ filter unit (Millipore, São Paulo, SP, Brazil) with a Durapore membrane (Millipore) with $0.5-\mathrm{mL}$ capacity.

HPLC data were collected and processed with a Shimadzu Class-VP 6.12 model apparatus (Kyoto, Japan) equipped with a diodearray detector and SP3 chromatographic software. The gradient of mobile phase elution was programmed for solvent A (acetonitrile: water, 5:95, v/v) and solvent B (acetonitrile: water, 90:10, v/v). The column was previously equilibrated with the mobile phase (100\% solvent A) for 30 min at a flow rate of $0.75 \mathrm{~mL} / \mathrm{min}$. The mobile phase was adjusted to $\mathrm{pH} 4.0$ with phosphoric acid. The flow rate was $0.75 \mathrm{~mL} / \mathrm{min}$ and the injection volume $20 \mu \mathrm{L}$. The column temperature was maintained at $25^{\circ} \mathrm{C}$ during analysis. The gradient program started with $0 \%$ of solvent $\mathrm{B}$ and increased linearly to $100 \%$ of solvent B in $30 \mathrm{~min}$ or $3.33 \% / \mathrm{min}$. Injections were performed in triplicate. After $44 \mathrm{~min}$, the elution program was returned to the initial condition and held there for $10 \mathrm{~min}$ in order to recondition the column.

\section{Treatments}

Mice fasted overnight, received the antihistamine agent, the $\mathrm{H}_{1}$-receptor antagonist promethazine $(10 \mathrm{mg} / \mathrm{kg})$ or aqueous extract $(25-100 \mathrm{mg} / \mathrm{kg}$ ) orally $(\mathrm{po})$ in a final volume of $200 \mu \mathrm{L}, 1 \mathrm{~h}$ before stimulation. The control groups were similarly treated with vehicle alone. In some experiments of allergic pleurisy, dexamethasone was given intraperitoneally $(2 \mathrm{mg} / \mathrm{kg}) 24$ and $1 \mathrm{~h}$ before stimulation ( $\mathrm{N}=7 /$ group$)$.

\section{Induction of paw edema}

Paw edema was induced as previously described (14). Briefly, Swiss mice received an intraplantar (ipl) injection of C48/80 (100 ng/paw), histamine (100 $\mu \mathrm{g} / \mathrm{paw})$, PAF (1 $\mu \mathrm{g} / \mathrm{paw})$, or 5 -HT $(100 \mu \mathrm{g} / \mathrm{paw})$ into one hind paw. The final volume was $50 \mu \mathrm{L}$ and the contralateral paw received the same volume of sterile saline and served as control ( $\mathrm{N}$ $=7$ /group). The volumes of each hind paw were measured with a plethysmograph (Ugo Basile, Varese, Italy) 30 min after stimulation.

Swiss mice sensitization and allergic paw edema were induced as described (15). Briefly, animals were sensitized with a subcutaneous injection of $100 \mu \mathrm{L}$ of a mixture of OVA (50 $\mu \mathrm{g}$ ), and aluminum hydroxide (5 mg). Fourteen days later, mice were challenged by an ipl injection of OVA ( $3 \mu \mathrm{g} / \mathrm{paw})$ and the induction of paw edema was evaluated 30 min after stimulation ( $\mathrm{N}=7$ /group).

\section{Allergic pleurisy}

Active sensitization of BALB/c mice was achieved with a subcutaneous injection of 
Freund's complete adjuvant emulsion (100 $\mu \mathrm{L})$ containing OVA $(100 \mu \mathrm{g})$. Fourteen days later, mice were challenged with an intrathoracic injection of OVA $(12.5 \mu \mathrm{g} /$ cavity, $\mathrm{N}=$ 7 /group) as described elsewhere $(16,17)$. Briefly, an adapted needle was inserted into the right side of the thoracic cavity of OVAsensitized animals to permit the intrapleural administration of OVA diluted in sterile pyrogen-free saline $(50 \mu \mathrm{L})$. Sensitized mice challenged with saline vehicle alone were used as negative controls.

At $24 \mathrm{~h}$ after the stimulus, mice were killed with excess carbon dioxide and their thoracic cavities were rinsed with $1 \mathrm{~mL}$ PBS containing $10 \mathrm{mM}$ EDTA, pH 7.4. Total leukocyte counts were made with an automatic Coulter counter (Beckman Coulter, Fullerton, CA, USA). Differential cell counts were made using stained cytospin (Shandon, Pittsburgh, PA, USA) by the May-Gruenwald-Giemsa method under light microscopy (100X). Counts are reported as numbers of cells $\left(\mathrm{x} 10^{6}\right)$ per cavity.

\section{Enzyme-linked immunosorbent assay}

Levels of eotaxin and IL-5 in the cellfree pleural fluid were evaluated by sandwich enzyme-linked immunosorbent assay using matched antibody pairs from Pharmingen (San Diego, CA, USA), according to manufacturer instructions. Results are reported as picograms per cavity of two experiments in triplicate and values were obtained by comparison with a standard curve (0.015-15 ng/mL for eotaxin and IL-5).

\section{Mast cell purification and histamine measurement}

Rat peritoneal mast cells were isolated as previously described (18). Briefly, male Wistar rats $(\mathrm{N}=7$ /group) were killed with excess carbon dioxide and the peritoneal cavity was rinsed with $20 \mathrm{~mL}$ of heparinized (10 IU/mL) calcium- and magnesium-free
Hank's solution (HBSS-). The fluid was collected, centrifuged at $150 \mathrm{~g}$ for $10 \mathrm{~min}$ at $4^{\circ} \mathrm{C}$, the pelleted cells were resuspended in $\mathrm{HSSB}^{-}$containing $0.1 \%$ bovine serum albumin and submitted to a continuous isotonic Percoll gradient (72\%) for mast cell isolation. Purified mast cells were resuspended in HSSB containing $\mathrm{Ca}^{2+}$ and $\mathrm{Mg}^{2+}$. Purity $(95 \%)$ and viability (98\%) were evaluated by Toluidine blue and Trypan blue exclusion staining, respectively. The cells were added to a 24 -well plate $\left(10^{5}\right.$ cells/well) and preincubated for $1 \mathrm{~h}$ with $1 \mu \mathrm{g} / \mathrm{mL}$ of dried SC extract dissolved in saline or with disodium cromoglycate at $10.2 \mu \mathrm{g} / \mathrm{mL}$ in a $5 \%$ $\mathrm{CO}_{2}$ atmosphere, at $37^{\circ} \mathrm{C}$. After this period, cells were incubated for $30 \mathrm{~min}$ with $5 \mu \mathrm{g} /$ $\mathrm{mL} \mathrm{C48/80.} \mathrm{The} \mathrm{reaction} \mathrm{was} \mathrm{stopped} \mathrm{in} \mathrm{ice.}$ Histamine was quantified in the supernatant by a fluorimetric assay as previously described (19). The fluorescence intensity was measured at $450 \mathrm{~nm}$ (excitation at $360 \mathrm{~nm}$ ) with a Spectra Max Gemini EM spectrofluorometer (Molecular Devices, Sunnyvale, CA, USA). Percent inhibition of histamine release was calculated as follows: \% inhibition $=100-\{($ histamine release with SC x 100) $/$ histamine release without $\mathrm{SC}\}$.

\section{Statistical analysis}

Data are reported as means \pm SEM and were analyzed statistically by one-way ANOVA, and differences between groups were assessed using the Student-NewmanKeuls post-test. A $\mathrm{P}$ value $<0.05$ was considered significant.

\section{Results}

\section{Chemical characterization of the extract}

The yield of the crude aqueous extract was $6.5 \%$ based on fresh leaves ( $\mathrm{g} / \mathrm{g}$ leaves). HPLC fingerprinting of the aqueous SC leaf extract showed an elution diagram consistent with the presence of tannins and flavonoids (Figure 
1A). The peaks were grouped into three regions based on the UV absorption profile, and these regions showed the typical patterns of UV absorption, supporting the presence of ellagitannin (Figure 1B), gallotannin (Figure 1C) and flavonoids (Figure 1D) in SC. The presence of flavonoids was also observed by TLC using NP/PEG (data not shown).

\section{Effect of Syzygium cumini extract on paw edema triggered by compound $48 / 80$ or ovalbumin}

To assess the effect of SC extract (crude extract obtained from fresh leaves by decoction in water) on allergic reactions, we first used the model of anaphylaxis edema caused by the mast-cell degranulator $\mathrm{C} 48 / 80$ or by OVA in sensitized animals. The $i p l$ administration of C48/80 into the mouse hind paw triggered a significant edema $30 \mathrm{~min}$ after the injection, as shown in Figure 2A. Oral pre-treatment with SC extract inhibited edema formation at doses of 25,50 , and 100 $\mathrm{mg} / \mathrm{kg}$ (maximal inhibition of $50 \%$ at $25 \mathrm{mg} /$ $\mathrm{kg}$ ) to almost the same extent as promethazine, an anti-histaminic compound (65\% inhibition at the dose of $10 \mathrm{mg} / \mathrm{kg}$; Figure 2A, inset). It is noteworthy that oral treatment with 200 or $400 \mathrm{mg} / \mathrm{kg} \mathrm{SC}$ extract inhibited edema formation at the same intensity (64 and $58 \%$ ). Figure $2 \mathrm{~B}$ shows that OVA (50 $\mu \mathrm{g})$ triggered paw swelling within $30 \mathrm{~min}$ in sensitized mice. Oral pre-treatment with SC extract $(25-100 \mathrm{mg} / \mathrm{kg}$ ) led to a slight (20\%) inhibition of allergic paw edema with no differences observed between the doses tested, even when we used the doses of 200 or $400 \mathrm{mg} / \mathrm{kg}$ of oral SC extract (25 and $32.8 \%$ inhibition, respectively; data not shown). Conversely, pre-treatment with promethazine $(10 \mathrm{mg} / \mathrm{kg}$; po $)$ was able to
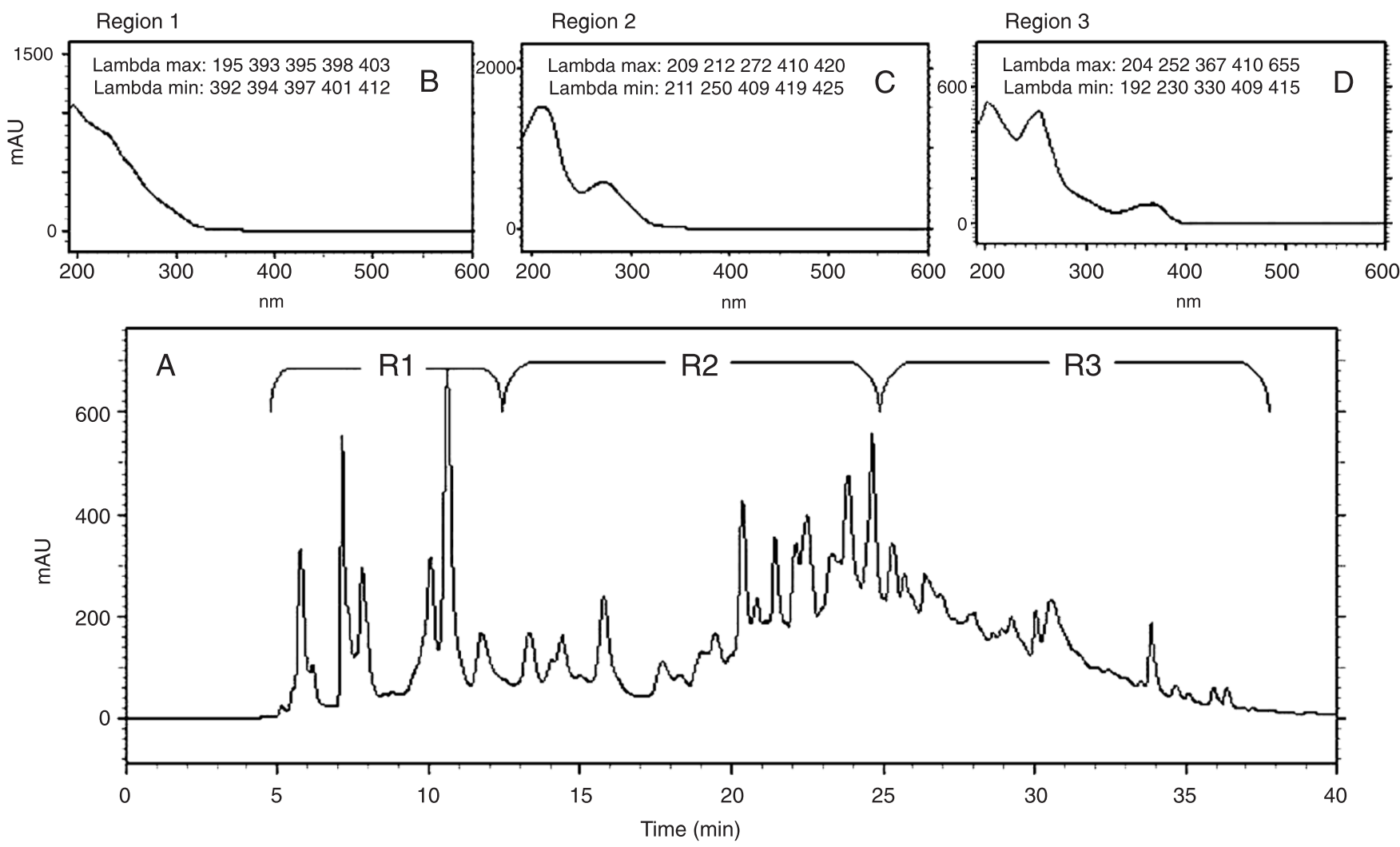

Figure 1. HPLC fingerprint of the Syzygium cumini aqueous leaf extract $(\lambda=280 \mathrm{~nm}$; $A)$ showing typical patterns of ellagitannins (B), gallotannins (C), and flavonoids (D) in the UV-visible absorption spectra. 
inhibit edema by $50 \%$ (Figure 2B, insert).

\section{Effect of Syzygium cumini extract on paw edema triggered by different inflammatory mediators}

Histamine, 5-HT and PAF are the major inflammatory mediators involved in allergic edema formation. In an attempt to understand the effect of SC, we analyzed the effect

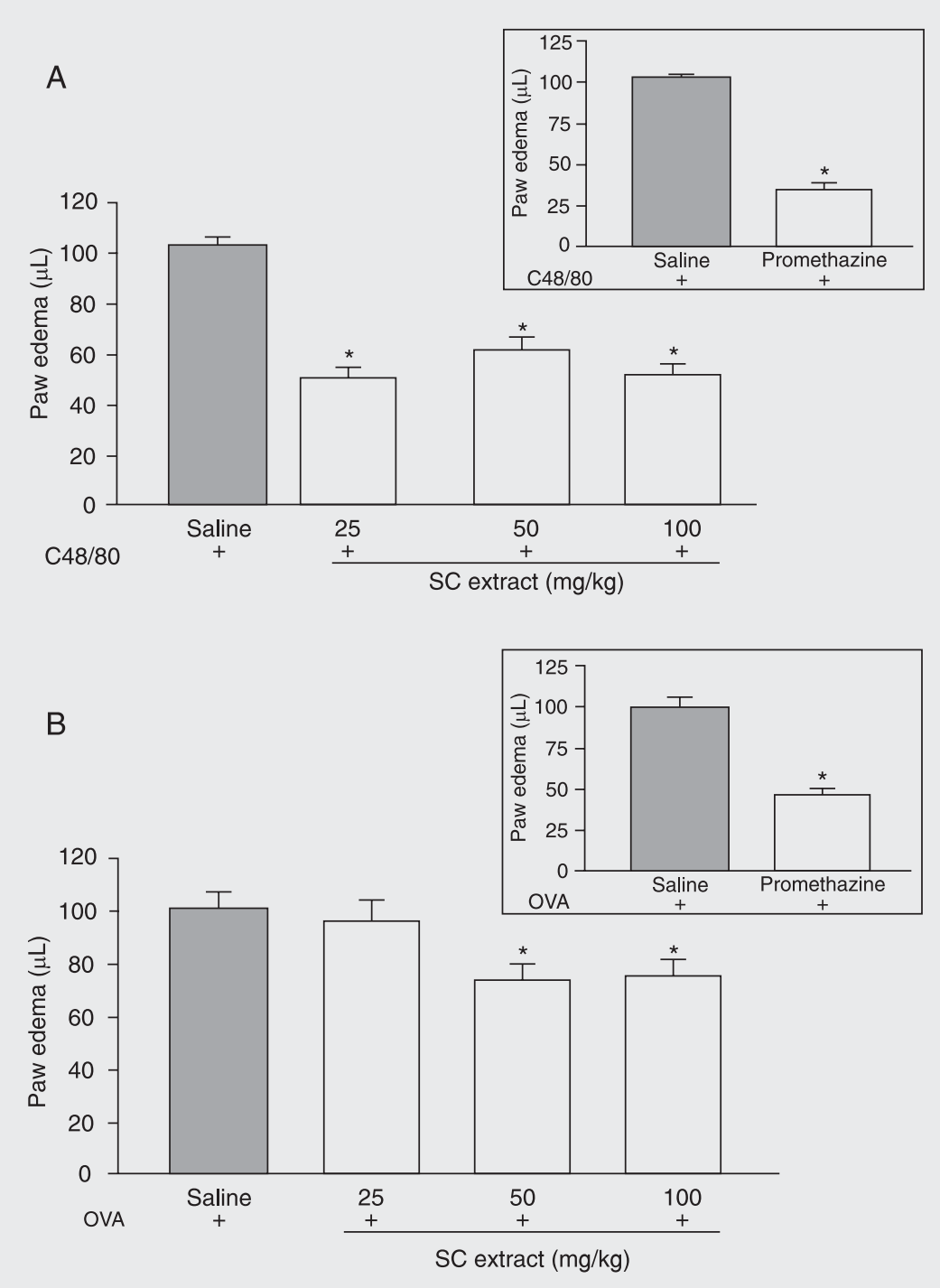

Figure 2. Effect of oral pre-treatment with different doses of aqueous extract of Syzygium cumini (SC) leaves on paw edema induced by compound 48/80 (C48/80, $100 \mathrm{ng} / \mathrm{paw}$; Panel A) or ovalbumin (OVA, $3 \mu \mathrm{g} / \mathrm{paw}$; Panel B). Promethazine $(10 \mathrm{mg} / \mathrm{kg}, \mathrm{po})$ was used as reference inhibitor (inset). Data are reported as the mean \pm SEM for at least 7 animals. ${ }^{*} \mathrm{P} \leq$ 0.05 compared to saline control (Student-Newman-Keuls post-test). of the extract against the edema induced by each of these mediators. As observed in Figure 3A, ipl injection of histamine (100 $\mu \mathrm{g} / \mathrm{paw}$ ) into the hind paw of naive mice induced a significant paw edema $30 \mathrm{~min}$ after the injection which was inhibited by oral treatment with SC extract, with a maximal inhibition of $58 \%$ achieved at $50 \mathrm{mg} / \mathrm{kg}$ $(\mathrm{P} \leq 0.05)$. Figure 3B shows that the ipl injection of 5-HT ( $100 \mu \mathrm{g} / \mathrm{paw})$ into the hind paw induced a significant paw edema 30 min after the stimulus, which was inhibited by treatment with $\mathrm{SC}$ at the dose of $100 \mathrm{mg} /$ $\mathrm{kg}(51 \%$ inhibition; $\mathrm{P} \leq 0.05)$. Conversely, the mouse paw edema induced by PAF (1 $\mu \mathrm{g} / \mathrm{paw}$; $30 \mathrm{~min}$ ) was not affected by oral pre-treatment with SC extract at the doses of 25,50 , or $100 \mathrm{mg} / \mathrm{kg}$ (Figure 3C). These results suggest that the anti-edematogenic effect of oral SC extract on allergen-induced paw swelling was due to an anti-histamine and anti-serotonin effect.

\section{Effect of Syzygium cumini extract on histamine release from rat peritoneal mast cells}

Mast cell degranulation followed by the release of vasodilating mediators (mainly histamine) is the major component of allergic edema. In this set of experiments we investigated the effect of the SC extract on mast cell degranulation by means of histamine release. As shown in Table 1, stimulation with C48/80 $(5 \mu \mathrm{g} / \mathrm{mL}$ ) induced the release of $20 \mathrm{ng} / \mathrm{mL}$ histamine in rat peritoneal mast cells that was inhibited by treatment with disodium cromoglycate, a classic mast cell membrane stabilizer (31\% inhibition). Pre-treatment with SC extract $(1 \mu \mathrm{g} / \mathrm{mL}, 1 \mathrm{~h}$ before C48/80) significantly inhibited the release of histamine from mast cells $(49.5 \%)$.

\section{Effect of Syzygium cumini extract on allergic pleurisy}

Twenty-four hours after the intrathoracic 
injection of OVA (12.5 $\mu \mathrm{g} /$ cavity), an intense accumulation of total leukocytes (Figure 4A), mononuclear cells (Figure 4B) and eosinophils (Figure 4D) was observed, while remaining numbers of neutrophils were present in the pleural cavity of BALB/c mice (Figure 4C). Dexamethasone pre-treatment $(2 \mathrm{mg} / \mathrm{kg}$, intraperitoneally) significantly inhibited the influx of total leukocytes (76\%), mononuclear cells $(62 \%)$ and eosinophils (99\% inhibition). The oral administration of SC $(100 \mathrm{mg} / \mathrm{kg}) 1 \mathrm{~h}$ before stimulation markedly inhibited the eosinophil accumulation (75\% inhibition, $\mathrm{P} \leq$ $0.001)$ in the pleural cavity. It is important to note that this inhibition was selective, with no effect on the numbers of total leukocytes, mononuclear cells or neutrophils.

\section{Inhibition of CCL11/eotaxin and IL-5 production by Syzygium cumini extract}

In order to understand the effects of the SC extract on eosinophil mobilization during an allergic inflammation, we investigated the effect of in vivo oral pre-treatment with SC on CCL11/eotaxin and IL-5 levels in pleural wash fluid. As observed in Figure 5 , intrathoracic antigen challenge significantly increased the levels of CCL11/eotaxin and IL-5 in pleural lavage fluid of sensitized animals $24 \mathrm{~h}$ after the challenge $(\mathrm{N}=7 /$ group; $\mathrm{P} \leq 0.05)$. Oral treatment with the SC extract led to a decrease in the levels of IL-5 (from $70.9 \pm 25.2$ to $12.05 \pm 7.165$ $\mathrm{pg} / \mathrm{mL}$; two experiments in triplicate; $\mathrm{P} \leq$ 0.05 ) and CCL11/eotaxin (from 60.4 \pm 8.54 to $32.8 \pm 8.4 \mathrm{ng} / \mathrm{mL}$; two experiments in triplicate; $\mathrm{P} \leq 0.05$ ) in pleural wash fluid. This effect was similar to the inhibition observed after dexamethasone treatment (from $70.9 \pm 25.2$ to $4.29 \pm 2.60 \mathrm{pg} / \mathrm{mL}$ IL-5 and from $60.4 \pm 8.54$ to $13.40 \pm 3.91 \mathrm{ng} / \mathrm{mL}$ CCL11/eotaxin).

\section{Discussion}

The results of the current study demon-
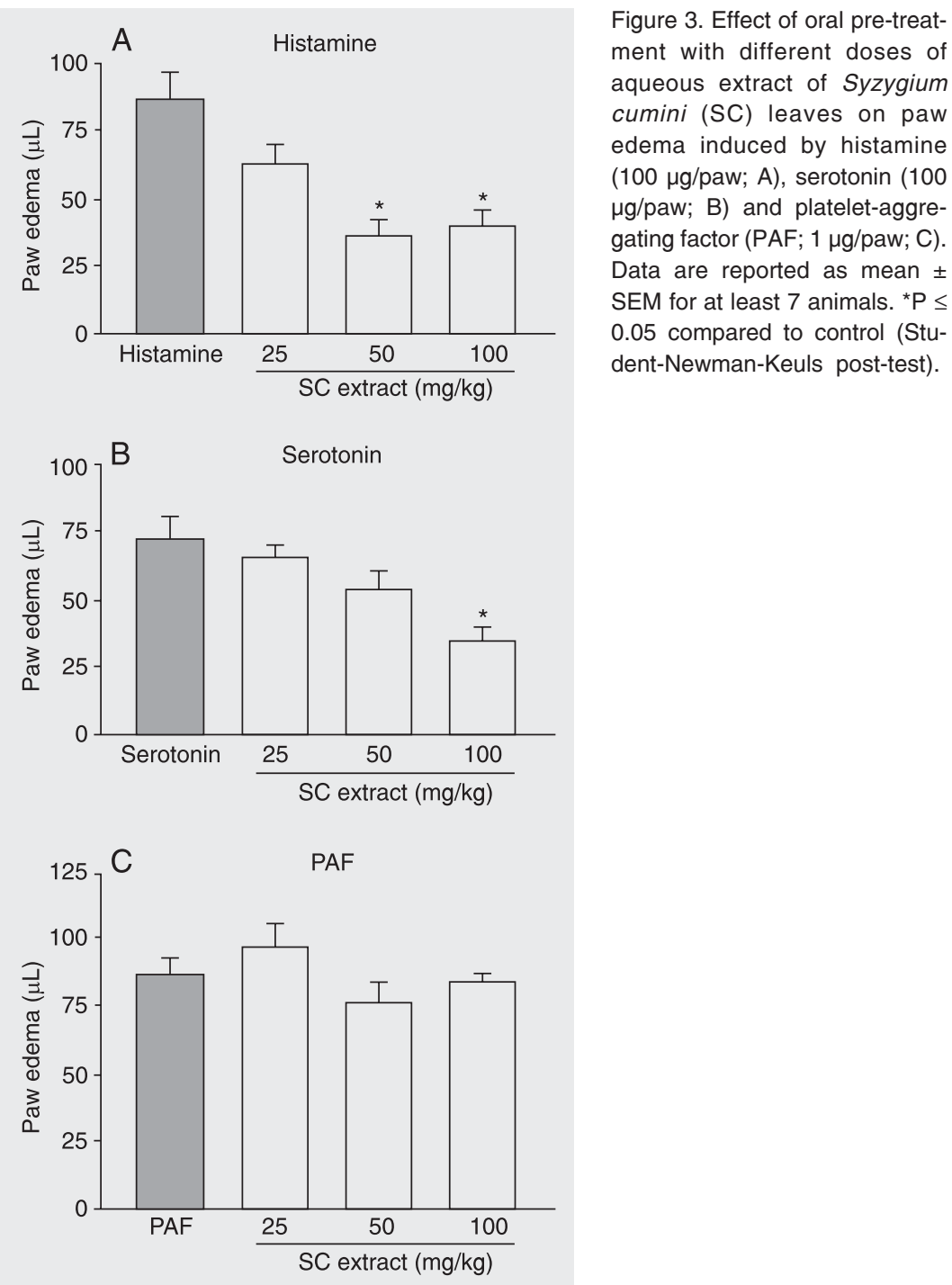

Table 1. Effect of Syzygium cumini extract and disodium cromoglycate on histamine release from rat peritoneal mast cells challenged in vitro with compound 48/80.

\begin{tabular}{lcc} 
Groups & Histamine release $(\mathrm{ng} / \mathrm{mL})$ & \% Inhibition \\
\hline Mast cells + medium & $2.1 \pm 1.4$ & \\
Mast cells + C48/80 & $20.0 \pm 5.0$ & 0 \\
DSCG + C48/80 & $13.8 \pm 2.6$ & 31.0 \\
SC extract + C48/80 & $10.1 \pm 6.1$ & 49.5
\end{tabular}

Data regarding histamine release are reported as the mean \pm SD of two experiments in triplicate. Rat peritoneal mast cells were incubated with $S$. cumini extract (SC; $1 \mu \mathrm{g} /$ $\mathrm{mL}$ ) or disodium cromoglycate (DSCG; $10.2 \mu \mathrm{g} / \mathrm{mL}$ ) and challenged in vitro with compound $48 / 80(\mathrm{C} 48 / 80 ; 5 \mu \mathrm{g} / \mathrm{mL}) 1 \mathrm{~h}$ later. Histamine present in the supernatant was quantified by fluorimetric assay. 
strate that the leaf extract of SC displays a marked anti-allergic property. Treatment with the SC extract inhibited the paw edema induced by C48/80, a potent mast cell degranulator, to an extent comparable to the effect of promethazine, a classical anti-histaminic used to relieve symptoms of allergic reactions. Treatment with the SC extract also inhibited the paw edema triggered by antigen challenge, although this effect on allergic paw edema was not equivalent to the effect observed on C48/80-induced edema.
Moreover, these results indicate a different mechanism of inhibition of $\mathrm{C} 48 / 80$ and antigen-induced paw edema by the SC extract, suggesting an action on specific targets.

Histamine, 5-HT and PAF have been extensively reported to be the major mediators involved in allergic edema formation. Supporting these observations, treatment with SC displayed an inhibitory effect on edema induced by histamine and 5-HT, but failed to inhibit PAF-induced paw edema. The participation of PAF in edema forma-
Figure 4. Inhibition of allergic pleurisy by oral pre-treatment (1 h) with the aqueous extract of Syzygium cumini (SC) leaves $(100 \mathrm{mg} / \mathrm{kg})$. Pleurisy was induced in 14 day-sensitized mice by antigen challenge (ovalbumin, OVA: $12.5 \mu \mathrm{g} /$ cavity). Total leukocyte $(A)$, mononuclear cell (B), neutrophil (C), and eosinophil (D) counts were performed $24 \mathrm{~h}$ after challenge. Data are reported as the mean \pm SEM for at least 7 animals. Dexa $=$ dexamethasone. ${ }^{+} \mathrm{P} \leq 0.05$ compared to saline group; ${ }^{*} P \leq 0.05 \mathrm{com}$ pared to untreated group (Student-Newman-Keuls post-test).
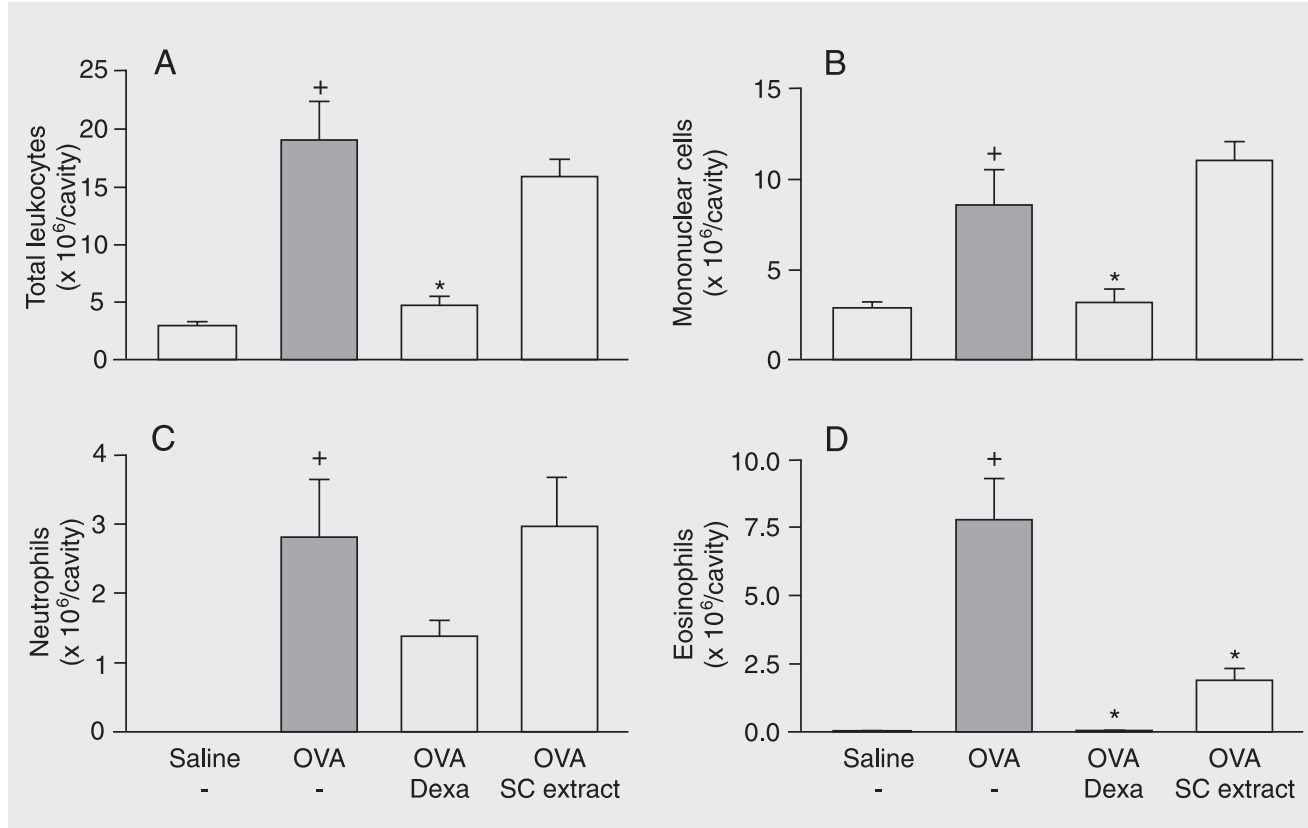

Figure 5. Effect of oral pre-treatment $(1 \mathrm{~h})$ with the aqueous extract of Syzygium cumini (SC) leaves $(100 \mathrm{mg} / \mathrm{kg})$ on interleukin-5 (A) and CCL11/eotaxin (B) generation in ovalbumin (OVA)stimulated mice. Protein levels were determined by ELISA in pleural washes recovered $24 \mathrm{~h}$ after saline or OVA (12.5 $\mu \mathrm{g} / \mathrm{cav}$ ity) stimulation, compared with pleural washes recovered from mice pre-treated with dexamethasone (Dexa, $2 \mathrm{mg} / \mathrm{kg}$; ip) or SC $(100 \mathrm{mg} / \mathrm{kg}, \mathrm{po})$ and injected with OVA. $+\mathrm{P} \leq 0.05$ compared to saline group; ${ }^{*} P \leq 0.05$ compared to untreated group (Student-Newman-Keuls post-test).

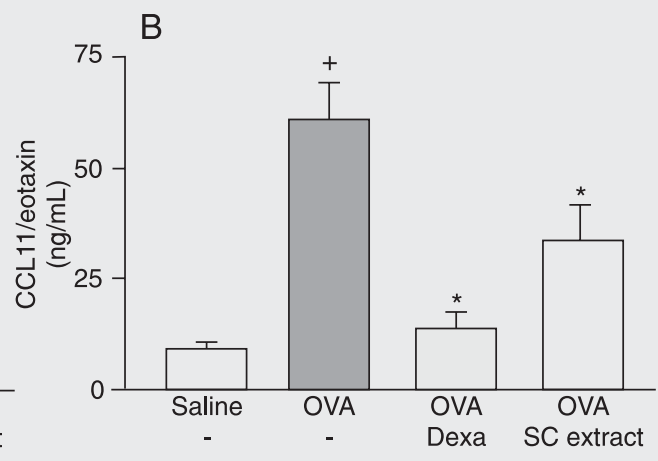

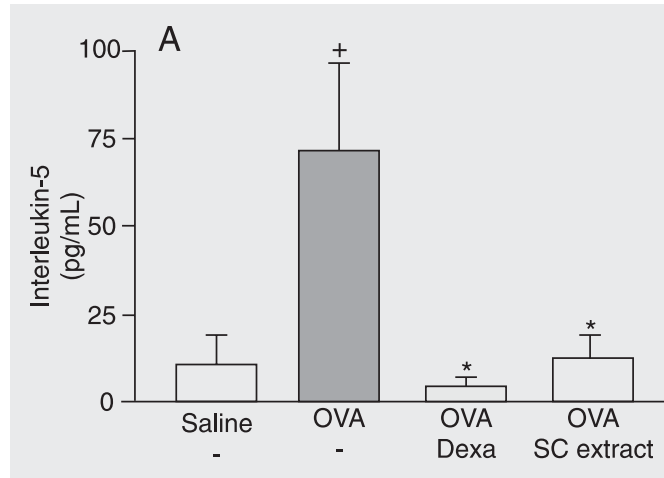


tion and eosinophil mobilization in allergic inflammation has been reported $(20,21)$ and the lack of effect of the SC extract on PAFinduced edema and the participation of the other mediators in the triggering of allergic paw edema may account for discrete effect of the SC extract on allergic paw edema. These results suggest that the SC extract can be much more effective in inhibiting reactions whose mechanism depends on the release of histamine and of 5-HT.

Kim and colleagues (3) showed that treatment with an aqueous extract of $S$. aromaticum (L.) Merr. et Perry (Myrtaceae) flower buds had an inhibitory effect on C48/80induced systemic anaphylaxis and IgE-mediated passive cutaneous anaphylaxis reaction. These results were due to an inhibitory action of this extract on histamine release from mast cells. In agreement with this report, we observed that the SC extract also had a direct effect on mast cell degranulation, inhibiting in vitro the histamine release induced by $\mathrm{C} 48 / 80$. This result suggests that the anti-edematogenic effect of SC on C48/ 80 or antigen-induced paw edema may be due to an action on the mast cell degranulation process. However, the effect of SC leaf extract on the edema triggered by exogenous histamine and serotonin also suggests that the SC extract has a direct effect on the inhibition of these mediators.

The presence of polyphenol, gallic acid, ellagic acid derivatives $(22,23)$, tannins $(24$, $25)$, and glycosylated flavonoids $(23,26,27)$ has been reported in Syzygium species. We extended the previous observation that SC leaf extracts contain flavonoids $(23,27)$. Ramirez and Roa Jr. (28) showed a correlation between the anti-inflammatory activity and the content of total phenolic compounds in the extracts of SC. Our results on the antiedematogenic effect of the SC extract also support the earlier observation of Slowing and colleagues (29) that the presence of flavonoid glycosides may be associated with the anti-inflammatory activity of a methanol extract of E. jambos leaves. The presence of phenolic compounds, especially flavonoids, in the aqueous extract of SC leaves and its anti-edematogenic activity justify the use of aqueous extracts and infusions of the plant in folk medicine.

Treatment with the SC extract inhibited eosinophil accumulation in allergic pleurisy, without a significant change in mononuclear cell or neutrophil recruitment. This treatment also inhibited the rise of IL- 5 and CCL11/eotaxin levels in pleural lavage fluid in allergic pleurisy.

Eosinophils play an important role in the pathophysiology of allergic diseases $(30,31)$. The accumulation and survival of these cells are regulated by IL- 5 secreted by activated T lymphocytes, as well as by chemokines released by the epithelium. Among the C-C chemokines, CCL11/eotaxin, an eosinophilspecific chemoattractant, is one of the most important mediators of allergic inflammation, with a potent and selective effect in mobilizing eosinophils from bone marrow to the blood (11,32-34). The effect of treatment with the SC extract on IL-5 and CCL11/ eotaxin levels may explain the specific inhibition of eosinophil accumulation induced by SC.

These activities of the SC extract may probably be due to the presence of flavonoids in the extract, since these substances isolated from Myrtaceae species, including SC, are known to exert a potent inhibitory effect on a variety of enzymes related to cell activation and to the production of inflammatory mediators $(35,36)$. Some isolated flavonoids possess anti-inflammatory (37), antiallergic (38) and analgesic (39) activities; however, few flavonoids from SC leaves $(23,27)$ and flowers have been isolated or identified (40).

Our findings indicate an anti-allergic activity of the SC extract observed by the inhibition of edema formation, mast cell degranulation and histamine release as well as the inhibition of eosinophil accumulation 
and CCL11/eotaxin and IL-5 production. Taken together, the present results suggest the potential of SC as a herbal-based therapy for the treatment of allergic diseases.

\section{Acknowledgments}

The authors thank Mr. Sérgio Monteiro and Dr. Graziela Barrozo (in memoriam) (Botanic Garden of Rio de Janeiro, UFRJ, Rio de Janeiro, RJ, Brazil), for technical support. The authors would also like to thank Dr. Benjamin Gilbert (FarManguinhos, Oswaldo Cruz Foundation, Rio de Janeiro, RJ, Brazil) for comments on the work and manuscript.

\section{References}

1. Caceres A, Fletes L, Aguilar L, Ramirez O, Figueroa L, Taracena AM, et al. Plants used in Guatemala for the treatment of gastrointestinal disorders. 3. Confirmation of activity against enterobacteria of 16 plants. J Ethnopharmacol 1993; 38: 31-38.

2. Muruganandan S, Srinivasan K, Chandra S, Tandan SK, Lal J, Raviprakash V. Anti-inflammatory activity of Syzygium cumini bark. Fitoterapia 2001; 72: 369-375.

3. Kim HM, Lee EH, Hong SH, Song HJ, Shin MK, Kim SH, et al. Effect of Syzygium aromaticum extract on immediate hypersensitivity in rats. J Ethnopharmacol 1998; 60: 125-131.

4. Chopra RN, Chopra IC, Handa KL, Kapur LD. Chopra's indigenous drugs of India. Calcutta: U.N. Dhur and Sons. Pvt. Ltda.; 1958.

5. Chakraborty D, Mahapatra PK, Chaudhuri AK. A neuropsychopharmacological study of Syzygium cuminii. Planta Med 1986; 139-143.

6. Prince PS, Kamalakkannan N, Menon VP. Antidiabetic and antihyperlipidaemic effect of alcoholic Syzigium cumini seeds in alloxan induced diabetic albino rats. J Ethnopharmacol 2004; 91: 209-213.

7. Matsuo T, Hanamure N, Shimoi K, Nakamura Y, Tomita I. Identification of (+)-gallocatechin as a bio-antimutagenic compound in Psidium guava leaves. Phytochemistry 1994; 36: 1027-1029.

8. Muruganandan S, Pant S, Srinivasan K, Chandra S, Tandan SK, Lal $\mathrm{J}$, et al. Inhibitory role of Syzygium cumini on autacoid-induced inflammation in rats. Indian J Physiol Pharmacol 2002; 46: 482-486.

9. Shakoory B, Fitzgerald SM, Lee SA, Chi DS, Krishnaswamy G. The role of human mast cell-derived cytokines in eosinophil biology. $J$ Interferon Cytokine Res 2004; 24: 271-281.

10. Robinson D, Hamid Q, Bentley A, Ying S, Kay AB, Durham SR. Activation of CD4+ T cells, increased TH2-type cytokine mRNA expression, and eosinophil recruitment in bronchoalveolar lavage after allergen inhalation challenge in patients with atopic asthma. $J$ Allergy Clin Immunol 1993; 92: 313-324.

11. Palframan RT, Collins PD, Williams TJ, Rankin SM. Eotaxin induces a rapid release of eosinophils and their progenitors from the bone marrow. Blood 1998; 91: 2240-2248.

12. Adamko DJ, Odemuyiwa SO, Vethanayagam D, Mogbel R. The rise of the phoenix: the expanding role of the eosinophil in health and disease. Allergy 2005; 60: 13-22.

13. Zimmermann M. Ethical guidelines for investigations of experimental pain in conscious animals. Pain 1983; 16: 109-110.

14. Henriques MG, Silva PM, Martins MA, Flores CA, Cunha FQ, Assreuy-Filho J, et al. Mouse paw edema. A new model for inflammation? Braz J Med Biol Res 1987; 20: 243-249.

15. Sampaio AL, Rae GA, Orleans-Juste P, Henriques MG. ETA receptor antagonists inhibit allergic inflammation in the mouse. $J$ Cardio- vasc Pharmacol 1995; 26 (Suppl 3): S416-S418.

16. Sampaio AL, Rae GA, Henriques MM. Role of endothelins on lymphocyte accumulation in allergic pleurisy. $J$ Leukoc Biol 2000; 67: 189-195.

17. Henriques MG, Weg VB, Martins MA, Silva PM, Fernandes PD, Cordeiro RS, et al. Differential inhibition by two hetrazepine PAF antagonists of acute inflammation in the mouse. $\mathrm{Br} J$ Pharmacol 1990; 99: 164-168.

18. de Oliveira BE, de Frias Carvalho V, Diaz BL, Balduino A, Cordeiro RS, Martins MA, et al. Adoptive transfer of mast cells abolishes the inflammatory refractoriness to allergen in diabetic rats. Int Arch Allergy Immunol 2003; 131: 212-220.

19. Shore PA, Burkhalter A, Cohn VH Jr. A method for the fluorometric assay of histamine in tissues. J Pharmacol Exp Ther 1959; 127: 182-186.

20. Amorim CZ, Martins MA, Cordeiro RS, Vargaftig BB. Differential inhibition by the PAF receptor antagonist, WEB 2170, of allergic inflammation in single sensitized and boosted mice. Eur J Pharmacol 1992; 211: 29-33.

21. Martins MA, Castro Faria Neto HC, Bozza PT, Silva PM, Lima MC, Cordeiro RS, et al. Role of PAF in the allergic pleurisy caused by ovalbumin in actively sensitized rats. J Leukoc Biol 1993; 53: 104111.

22. Bhatia IS, Bajaj KL. Chemical constituents of the seeds and bark of Syzygium cumini. Planta Med 1975; 28: 346-352.

23. Timbola AK, Szpoganicz B, Branco A, Monache FD, Pizzolatti MG. A new flavonol from leaves of Eugenia jambolana. Fitoterapia 2002; 73: 174-176.

24. Tanaka T, Nonaka GI, Nishioka I, Kuono I. Syzyginins A and B, two ellagitannins from Syzygium aromaticum. Phytochemistry 1996; 43: 1345-1348.

25. Son K, Kwon SY, Kim HP, Chang HW, Kang SS. Constituents from Syzygium aromaticum Merr. et Perry. Nat Prod Sci 1998; 4: 263267.

26. Vaishnava MM, Gupta KR. Isorhamnetin 3-orutinoside from Syzygium cuminii Linn. J Chem Soc 1990; 67: 785-786.

27. Mahmoud II, Marzouk MS, Moharram FA, El-Gindi MR, Hassan AM. Acylated flavonol glycosides from Eugenia jambolana leaves. Phytochemistry 2001; 58: 1239-1244.

28. Ramirez RO, Roa CC Jr. The gastroprotective effect of tannins extracted from duhat (Syzygium cumini Skeels) bark on $\mathrm{HCl} /$ ethanol induced gastric mucosal injury in Sprague-Dawley rats. Clin Hemorheol Microcirc 2003; 29: 253-261.

29. Slowing K, Sollhuber M, Carretero E, Villar A. Flavonoid glycosides 
from Eugenia jambos. Phytochemistry 1994; 37: 255-258.

30. Wark PA, Gibson PG. Clinical usefulness of inflammatory markers in asthma. Am J Respir Med 2003; 2: 11-19.

31. Bochner BS, Busse WW. Advances in mechanisms of allergy. $J$ Allergy Clin Immunol 2004; 113: 868-875.

32. Jose PJ, Griffiths-Johnson DA, Collins PD, Walsh DT, Moqbel R, Totty NF, et al. Eotaxin: a potent eosinophil chemoattractant cytokine detected in a guinea pig model of allergic airways inflammation. J Exp Med 1994; 179: 881-887.

33. Rothenberg ME, Luster AD, Leder P. Murine eotaxin: an eosinophil chemoattractant inducible in endothelial cells and in interleukin 4induced tumor suppression. Proc Natl Acad Sci U S A 1995; 92: 8960-8964.

34. Baggiolini M, Dewald B, Moser B. Human chemokines: an update. Annu Rev Immunol 1997; 15: 675-705.

35. Middleton $E \mathrm{Jr}$. Effect of plant flavonoids on immune and inflamma- tory cell function. Adv Exp Med Biol 1998; 439: 175-182.

36. Gupta OP, Sing S, Bani S, Sharma N, Malhotra S, Gupta BD, et al. Anti-inflammatory and anti-arthritic activities of silymarin acting through inhibition of 5-lipoxygenase. Phytomedicine 2000; 7: 21-24.

37. Hiroshi U, Chikako Y, Masatoshi Y. Luteolin as antiinflammatory and anti-allergic constituent of Perilla fructens. Biol Pharm Bull 2002; 25: 1197-1202.

38. Cheong H, Ryu SY, Oak MH, Cheon SH, Yoo GS, Kim KM. Studies of structure activity relationship of flavonoids for the anti-allergic actions. Arch Pharm Res 1998; 21: 478-480.

39. Chou TC, Chang LP, Li CY, Wong CS, Yang SP. The antiinflammatory and analgesic effects of baicalin in carrageenan-evoked thermal hyperalgesia. Anesth Analg 2003; 97: 1724-1729.

40. Subramanian SS, Nair AGR. Flavonoids of the flowers of Eugenia jambolana. Curr Sci 1972; 703-704. 